\title{
SUPERVIVENCIAS MUDEJARES Y PRESENCIAS ORIENTALISTAS EN LA ARQUITECTURA MEXICANA
}

\section{Por Elisa Garcia Barragán}

"Entre los maravillosos tesoros de cultura que España distribuyó con mano generosa en el Nuevo Mundo, constituido actualmente por las Repúblicas Americanas, antaño colonias suyas, se cuenta el arte mudéjar", así, inicia Manuel Toussaint el prólogo de su magnífico libro El arte mudéjar en América, ${ }^{1}$ en el que da una visión general y de conjunto de la influencia que este arte tuvo en toda América, no sólo en la hispánica. Añade el autor: "El arte mudéjar es la expresión más subyugadora de la España anterior al Renacimiento, y ese arte sabe fundirse con el propio movimiento renacentista y prolongarse durante largos años a través de las Colonias." 2

En efecto, en México el gusto por las construcciones y ornamentación mudéjares se extendió durante toda la época virreinal y en el siglo xIX, después del paréntesis marcado por la Guerra de Independencia y primeros años de la República, continuaron haciéndose construcciones en las que pervivieron algunos elementos mudéjares como la "carpintería de lo blanco", sobre todo en las regiones serranas de los actuales Estados de Michoacán y Chiapas. Por otra parte, en el siglo xix hubo un movimiento en favor del arte morisco, emparentado con el mudéjar, registrado en las ciudades principales del país. Formó parte del eclecticismo de la arquitectura de dicho siglo. Esa especie de reactualización del arte morisco, a la que en España se llamó "neomudejarismo", terminó por confundirse con el romántico afán orientalista que tiñó todas las manifestaciones artísticas, tanto literarias como plásticas, de fines del siglo pasado y principios del presente. La inclinación a lo oriental, persiste aún en algunas muestras contemporảneas, la vemos sobrevivir en curiosos ejemplos realizados en pleno siglo $\mathrm{xx}$, algunos de ellos hechos hace apenas unos cuantos años.

Tanto las expresiones más puras y primeras de lo mudéjar en Mćxico, así como los elementos estructurales y decorativos de ese arte, que continuaron apareciendo en la arquitectura mexicana, mezclados con formas de otros estilos contemporáneos a ellas o posteriores, son de sobra

1 Toussaint, Manuel. El arte mudéjar en América. México, Ed. Porrúa, 1946, p. 3.

2 Toussaint. Manuel. Op. cit., p. 3. 
conocidos, y fueron ampliamente estudiados, entre otros, por don Manuel Toussaint, el primero que en México se ocupó del mudejarismo y quien gracias a la valiosa colaboración que le prestó su colega y amigo, el notable investigador español don Diego Angulo fñiguez, nos dejó el interesante libro antes mencionado. Por tal motivo, no me detendré en detallarlas, y sólo las mencionaré brevemente a manera de recordatorio, para hablar enseguida de algunos ejemplos de persistencia de temas mudéjares en el siglo XIX, que estimo serán novedosos.

Es preciso citar primero, como manifestaciones directas del arte mudéjar en México: las capillas de indios, tipo mezquita, como San José de los Naturales en la ciudad de México y la de Cholula (Puebla); los "rollos" o torres de vigilancia, tal vez muy numerosos en México, y de los que quedan el de Tepeaca, que recuerda a la Torre del Oro en Sevilla, y el de Tlaquiltenango; también algunas fuentes, entre las que destaca la monumental y extraordinaria de Chiapa de Corzo.

Las formas arquitectónicas de tipo mudéjar, empleadas con mayor frecuencia en la Colonia durante el siglo xvi, y aun en los dos siglos siguientes fueron: bóvedas sobre arcos cruzados, como la del Camarín de la Virgen en Tepotzotlán (siglo Xvil); los pilares ochavados, que se emplearon con más frecuencia durante todo el virreinato; otro tanto puede decirse de las ventanas geminadas, de las que es buen modelo la hecha en la torre del templo del que fue hospital de indios en Acámbaro, precedente de muchas otras que se produjeron, en particular, en los templos del Estado de Michoacán; por último, los alfarjes y artesonados mudéjares muy abundantes en el virreinato. Por los restos que aún se conservan de algunos, tales el de San Francisco en Tlaxcala, el de San Diego en Huejotzingo, el de Atotonilco de Tula o el de Angahua en Michoacán, etcétera, y las relaciones que existen en torno a otros, tenemos la certeza de su opulencia, tanto por el rico diseño de la "carpintería de lo blanco", como por el dorado y policromado que se les dio.

La magnificencia de las techumbres mudéjares, sobre todo en la ciudad de México, la describe Francisco de la Maza en el primer capítulo "Los artesones de oro", de su libro Ln ciudad de México en el siglo $X V I I$, por medio de los relatos de poetas y cronistas de la época y así, de la Grandeza mexicana, de Bernardo de Balbuena, toma los siguientes versos: ${ }^{3}$

3 De la Maza, Francisco, La ciudad de México en el siglo XVII. Fondo de Cultura Económica, 1968, p. 10. 
Toda ella en llamas de belleza se arde y se va como fénix renovando que es ver, sobre las nubes, ir volando con bellos lazos, las techumbres de oro de ricos templos que se van labrando.

Y más adelante:

Si en corvas cimbrias artesones de oro por las soberbias arquitrabes vuelan con ricos lazos de inmortal tesoro

De la misma manera son alabados el de la Profesa, iglesia mayor de los jesuitas; el Carmen; la capilla de San José en el atrio de San Francisco, o el bellísimo de la Merced que perduró hasta el año de 1867.

En el Estado de Michoacán, el arquitecto Manuel González Galván, en una reciente investigación, encontró que desde la época virreinal hasta nuestros días se ha venido prefiriendo ese tipo de cubiertas. El estudio de González Galván modifica la creencia de que el uso de la "carpintería de lo blanco" se había continuado hasta el siglo xix únicamente en las islas Canarias, las Antillas y Venezuela.

Los techos michoacanos, con ciertos cambios estructurales, que no les han hecho perder la forma de artesa invertida, suman a ésta otra innovación: en sus amplias superficies planas, suplen los oros y la decoración geométrica por pinturas con narraciones de la pasión de Cristo, de los misterios marianos, etcétera, y debido a eso, González Galván los bautiza con el nombre de "alfarjes historiados". Se trata pues, según dice este autor, de techumbres no sólo engalanadas, sino "didácticas".

El repertorio ornamental de ascendencia mudéjar, presenta una gran variedad: merlones piramidales en los almenados de algunos templos y conventos, como Huejotzingo, recuerdo de las almenas escalonadas de los edificios moros; la decoración con relieves de argamasa afectando formas geométricas o lacerías, por ejemplo, las que coronan el exterior de los muros de la iglesia de Tepotzotlán, o que cubren los paramen. tos de templos y edificios civiles de la ciudad de México, tales las ajaracas de San Juan de Dios y otras; azulejos que derivan de su uso inicial, hasta convertirse en el tipo distintivo de la ciudad de Puebla; los alfices, tal vez uno de los elementos mudéjares más empleados, que aparecen enmarcando infinidad de portadas religiosas del siglo Xvi, iglesias llenas de atractivo cuya característica principal es el hibridismo de su decora- 
ción como sucede con la del ya mencionado hospital de Acámbaro o la de Angahua en Michoacán.

Se usaron alfices como bocelones, cordones franciscanos o bien formados por franjas de ornamentación vegetal y su utilización se prolongó durante los siglos XVII y XvIII, algunas veces confundidos en la ornamentación barroca y otras en las que se nota que el arquitecto los emplea por su lógica compositiva ya que aislan la decoración, y centran la atención en ella, creando insulas decorativas como sucede ya en pleno siglo xvin en el convento de San Agustín en Zacatecas, en donde aparecen los alfices en la iglesia llenos de ornamentación vegetal, enmarcando los arcos del crucero de la nave. En el claustro más sobrios, en forma de moldura, que termina en un pequeño roleo, encuadran el arco de ascenso a la escalera y la entrada de lo que probablemente fue la sala capitular.

Las formas mudéjares vuelven a surgir con abundancia en la ciudad de México y en las principales ciudades del país en el último tercio del siglo xIx, por obra y gracia del movimiento romántico y del eclecticismo que, al igual que en Europa, caracterizó la arquitectura del siglo pasado, eclecticismo que derivaba de la "libertad en el arte", pregonada por Victor Hugo y de la filosofía ecléctica de Coussin; conjunto de ideas importadas por los arquitectos mexicanos que perfeccionaban sus conocimientos en el Viejo Mundo. Libertad que se refleja en la arquitectura mexicana a consecuencia de haber ocupado la dirección de la Academia, el arquitecto Cavallari, a quien se debe que en 1857, se impartiera por primera vez con ella la cátedra de Historia de la Arquitectura. Esa cátedra facilitó a los alumnos el proyectar en cualquier estilo, y no solamente ceñirse a las formas clásicas. Pudieron ver con simpatía y como dignas de estudio todas las culturas, porque en todas se encuentran aportaciones valiosas, y si en un principio la corriente romántica les hizo preferir el medievo, pocos años más tarde se inclinaron por los asuntos orientales, los que emplean primero asociados al gótico, triunfando más tarde el movimiento ecléctico.

El eclecticismo, sin lugar a dudas, se reforzó con la declaración de Juan de Dios de la Rada Delgado, ya que en su discurso de entrada a la Academia de San Fernando de Madrid, en 1882, titulado: "Cuál es y debe ser el carácter propio de la arquitectura del siglo xix", proclamó que el arte arquitectónico de ese siglo "tiene que ser ecléctico". " Se trataba pues de una postura exigida al arquitecto, y si las academias de

4 Navascues Palacio, Pedro. Arquitectura y arquitectos madrileños del siglo $X I X$. Madrid, Instituto de Estudios Madrileños, 1973, p. 237. 
España, especialmente la de San Fernando, habían impuesto sus cánones en nuestro país con anterioridad, como sucedió con el movimiento neoclásico. Es lógico suponer que, a pesar del afrancesamiento que imperaba en nuestro país en esos tiempos, una llamada de atención hecha por un destacado académico de San Fernando, no podía ser desoída en México que estaba en contacto constante con España a través de sus publicaciones y de su prensa periódica. En ese mismo discurso, Rada y Delgado pedía a los arquitectos que fundieran los elementos de todos los estilos para producir composiciones híbridas, pero cuidando de estudiar bien los estilos para "que no se haga un gótico de confitería y un arte árabe que sólo tenga de tal algún accesorio en el ornato", siempre abundando en la idea de que "un edificio neogótico puede perfectamente convivir con otro neobizantino y neogriego sin exclusión alguna". 5

En México, es importante aclarar, como lo hace el arquitecto Israel Katzman en su obra La arquitectura del siglo XIX en México, que:

En general cuando se habla de clásico, neogótico o neomorisco en el siglo $\mathrm{xIx}$, no se hace referencia a un retorno espacial, sino a cierto tratamiento decorativo y a las proporciones y posición de ciertos elementos aunque sólo se den en las fachadas. ${ }^{6}$

Eso es cierto, en México no hubo ningún retorno estilístico absolutamente fiel con un sentido historicista; se trata de simples grados de parentesco, por lo que en realidad resulta un atrevimiento llamar "neomudéjar" al grupo de edificaciones del siglo xIx, en las que persisten las formas mudéjares (arcos de herradura, polilobulados, almenas escalonadas, etcétera), sobre todo el empleo del ladrillo, aprovechando sus posibilidades decorativas; tal vez lo más correcto sería nombrarlas neomoriscas o simplemente orientalistas.

Es esa etapa de nuestra arquitectura, que tuvo un amplio desarrollo en el último tercio del siglo pasado y principios del presente, tanto en la ciudad de México como en la provincia, la que interesa mostrar en el presente trabajo, pues es poco conocida. El arquitecto Katzman en su obra antes señalada, asi como Antonio Bonet Correa en La arquitectura

5 Navascues Pacheco, Pedro, op. cit., p. 237.

- Katzman, Israel. Arquitectura del siglo XIX en México. México, UNAM, Centro de Estudios Arquitectónicos, 1973, p. 64. 
de la época porfiviana en México, ‘ únicos textos que se ocupan de ella, sólo mencionan la existencia de la corriente ecléctico-orientalista, y consignan algunos ejemplos. Mas si se profundiza en este tema, se en. cuentra que las primeras muestras de esa corriente se inspiraron en los pabellones árabes que España levantó para las exposiciones nacionales e internacionales, por ejemplo, en el edificio neomudéjar para la Exposición Internacional de Viena de 1873, diseñado por uno de los arquitectos representantes del neomudejarismo madrileño, Lorenzo Alvarez Capra, quien construyó, según describe Pedro Navascues Palacio, en su libro Arquitectura y arquitectos madrileños del siglo $X I X$ : "Un edificio de planta rectangular con cuatro cuerpos salientes en los ángulos. Todos los huecos llevaban arcos de herradura polilobulados, apareciendo además alfices, ladrillos en esquinilla y arcos entrecruzados. Se daba allí igualmente, una alternancia de ladrillos en dos tonos distintos." s

Esa policromía neomudéjar producida por el contraste del ladrillo, va a ser aprovechada por algunos arquitectos mexicanos, entre otros, Eduardo Tamariz, de Puebla, el que después de un viaje por Europa y Oriente, construyó en 1879 el hospital de maternidad en esa ciudad, en cuyos paramentos alternó, en fajas horizontales, ladrillos de dos colores, alternancia que también siguió en las dovelas de los arcos del patio. En la ciudad de México, esos antecedentes dieron lugar a una buena arquitectura de ladrillo, con sus vanos enmarcados por arcos de herradura, polilobulados algunas veces y con cornisas que coronaron almenas escalonadas. Este "seudomudejarismo" contagió a otros edificios, qué solamente tomaron algunos de esos elementos, agrupándolos a otros de corrientes diversas. Varias de esas construcciones, realizadas en los alrededores de la ciudad de México, y ya desaparecidas en la actualidad, nos ha sido posible conocerlas gracias a la revista Mundo Ilustrado, que en el año de 1899, publicó una sección que denominó "Alrededores de México", con fotografías de las casas interesantes de Mixcoac, Tlalpan, San Angel y Coyoacán".

Es oportuno nombrar aquí los edificios hecho en las ciudades de Aguascalientes y Zacatecas por el notable arquitecto sin título, y autodidacta, Refugio Reyes, quien empleó el ladrillo a la manera mudéjar en esas construcciones: su propia casa en la calle de Centenario, hoy

7 Bonet Correa, Antonio. La arquilectura de la epoca porfiriana en México. Espa. ña, Publicaciones de la Universidad de Murcia, 1966.

8 Navascues Palacio, Pedro, op. cit., p. 233. 
DOI: http://dx.doi.org/10.22201/iie.18703062e.1976.45.1037

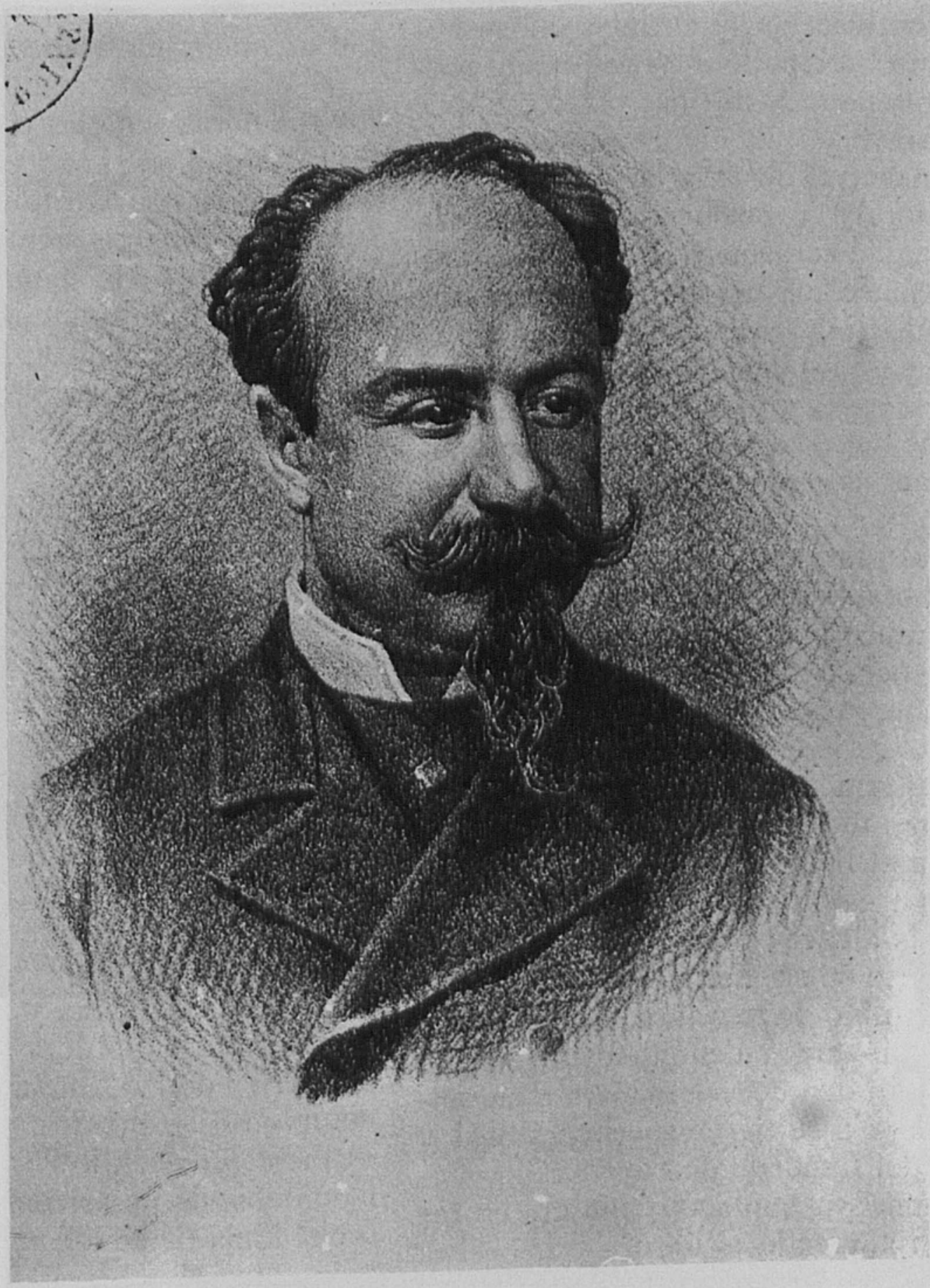

1. Ingeniero Ramón Ibarrola. Director de las construcciones mexicanas en la Exposición de Nueva Orleans. La Epoca Ilustrada, 24 de noviembre de 1884. 


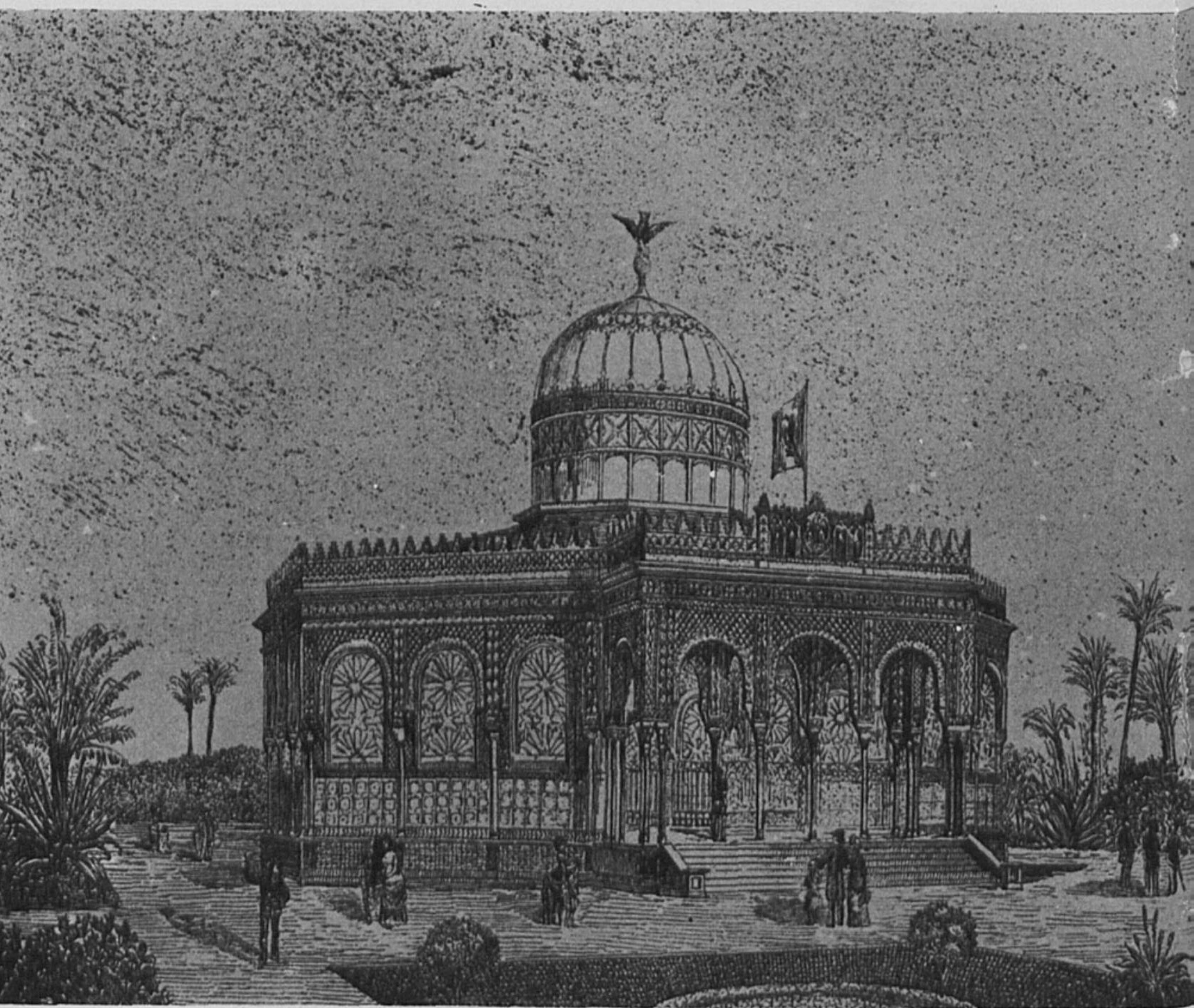

2. El pabellón morisco de la Alameda de Santa María. La Patria Ilustrada, 11 de mayo de 1885 . 


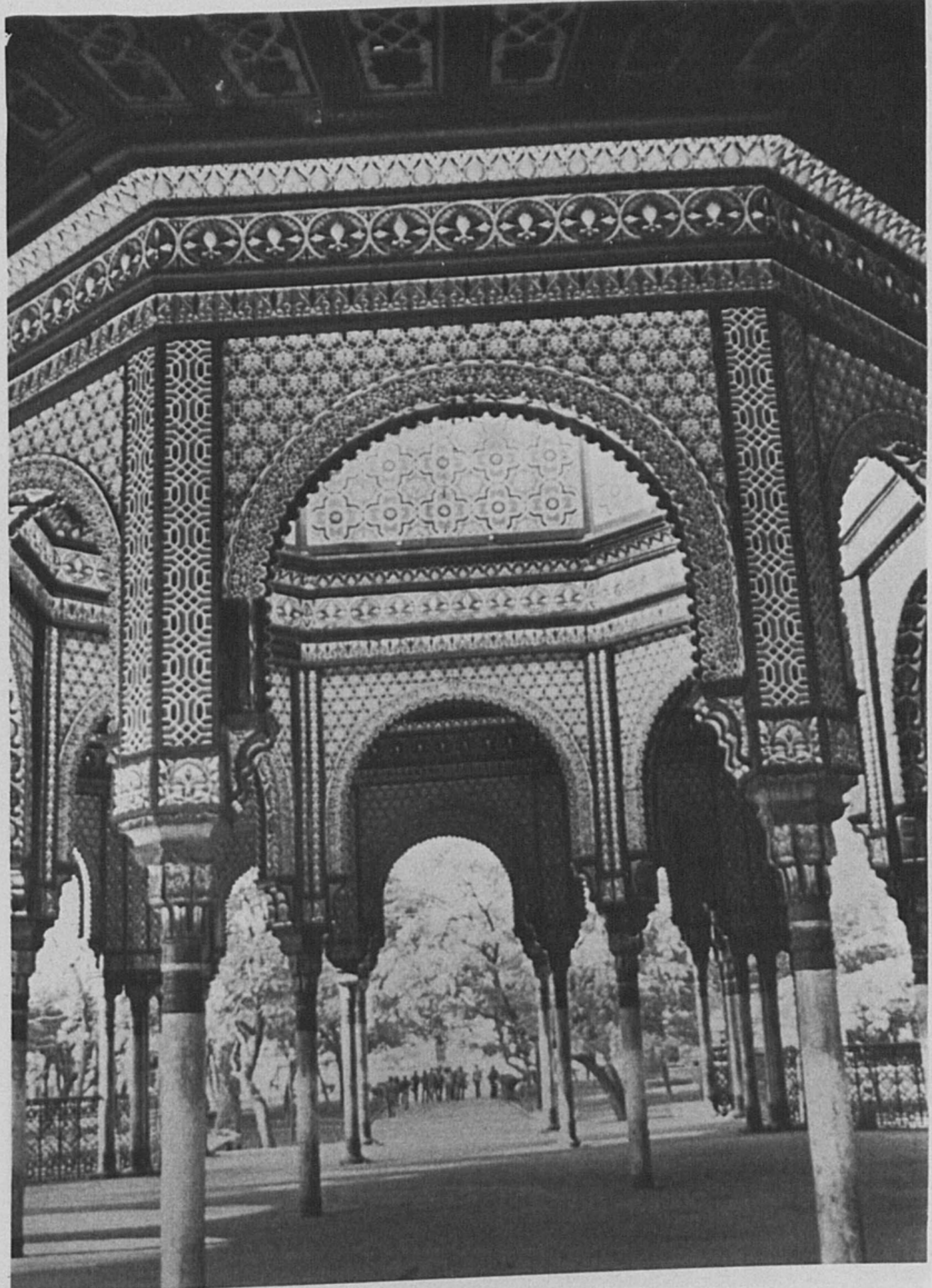

3. Interior del Pabellón morisco. Foto Pedro Cuevas. 

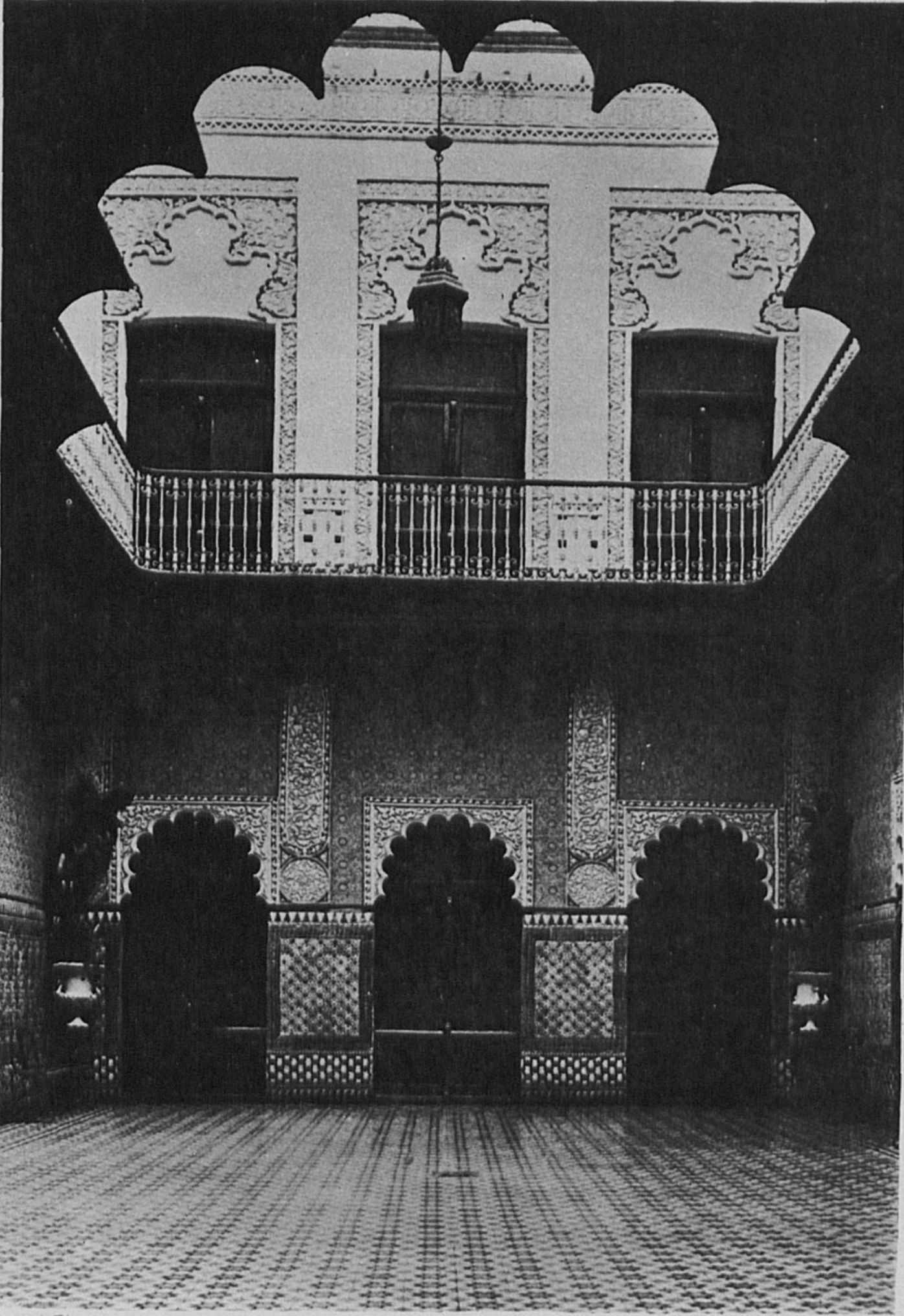

4. Casa de la sociedad de la Purísima Concepción. Arquitecto Eduardo Tamariz. Puebla, Pue., 1883. Foto arquitecto Israel Katzman. 


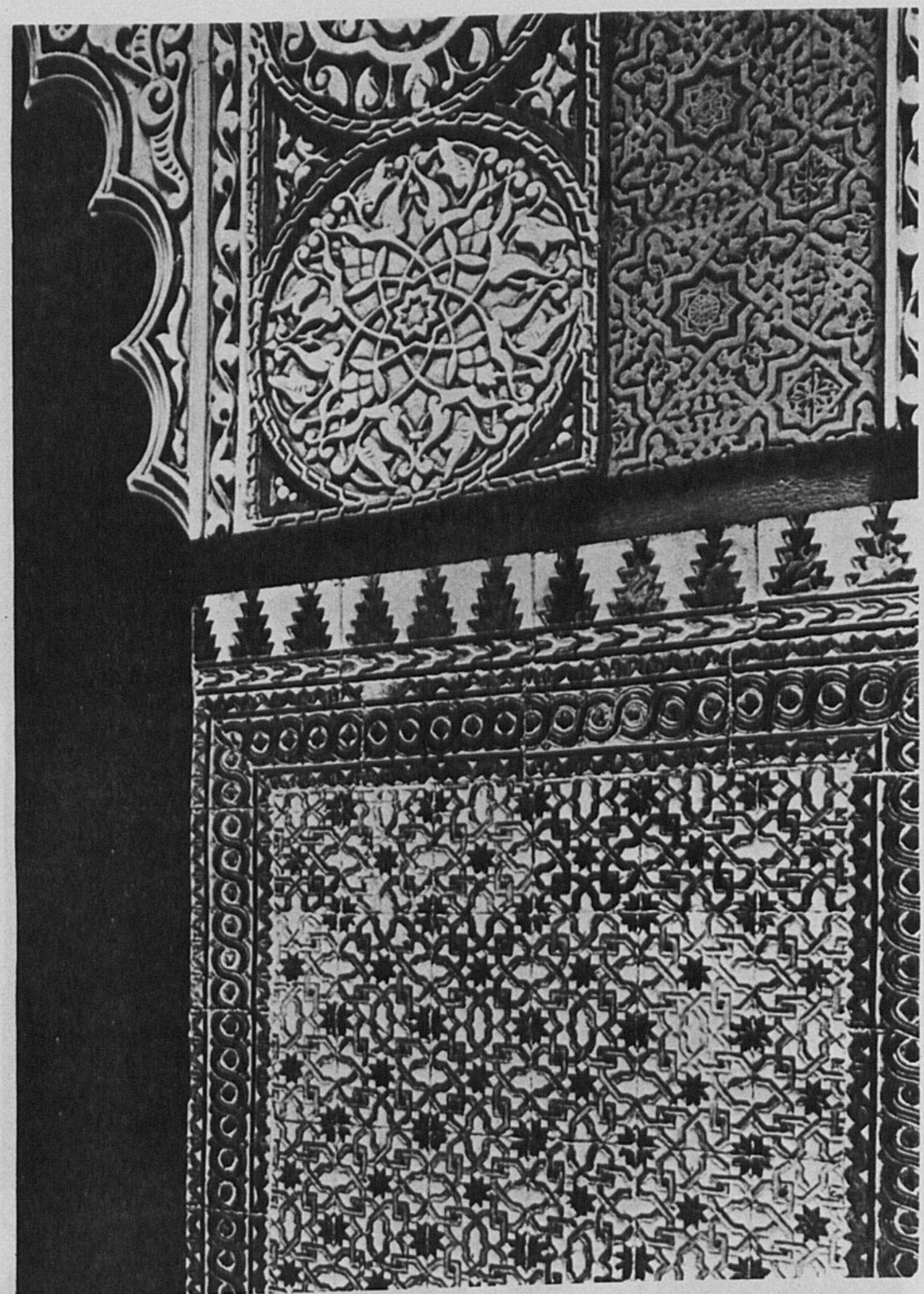

5. Casa de la Purísima Concepción. Arquitecto Eduardo Tamariz. Puebla, Pue. Foto arquitecto Israel Katzman. 


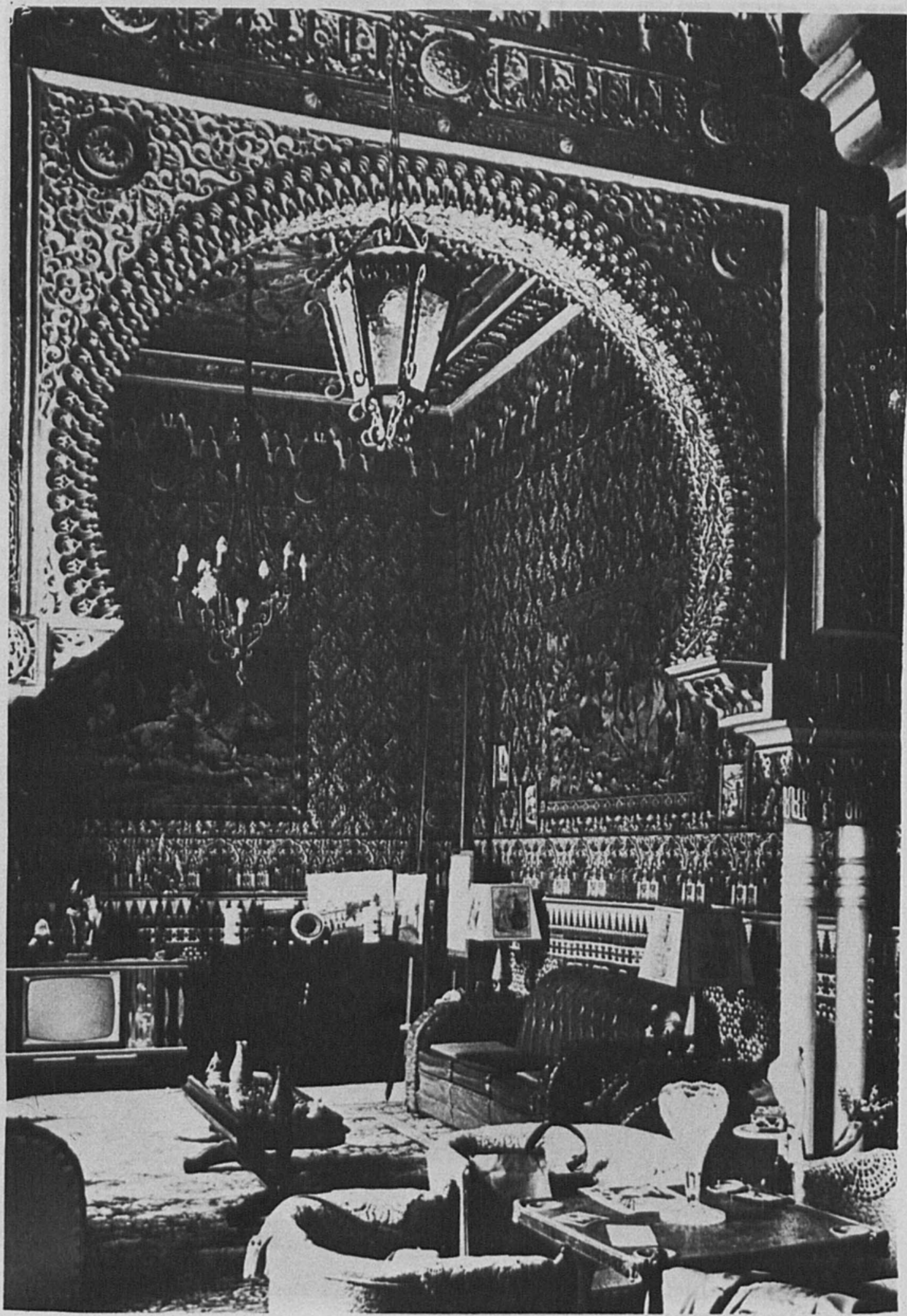

6. Fumador de la casa en 2 Norte 402. Puebla, Pue. Decoración de los hermanos Arpa. Foto arquitecto Israel Katzman. 


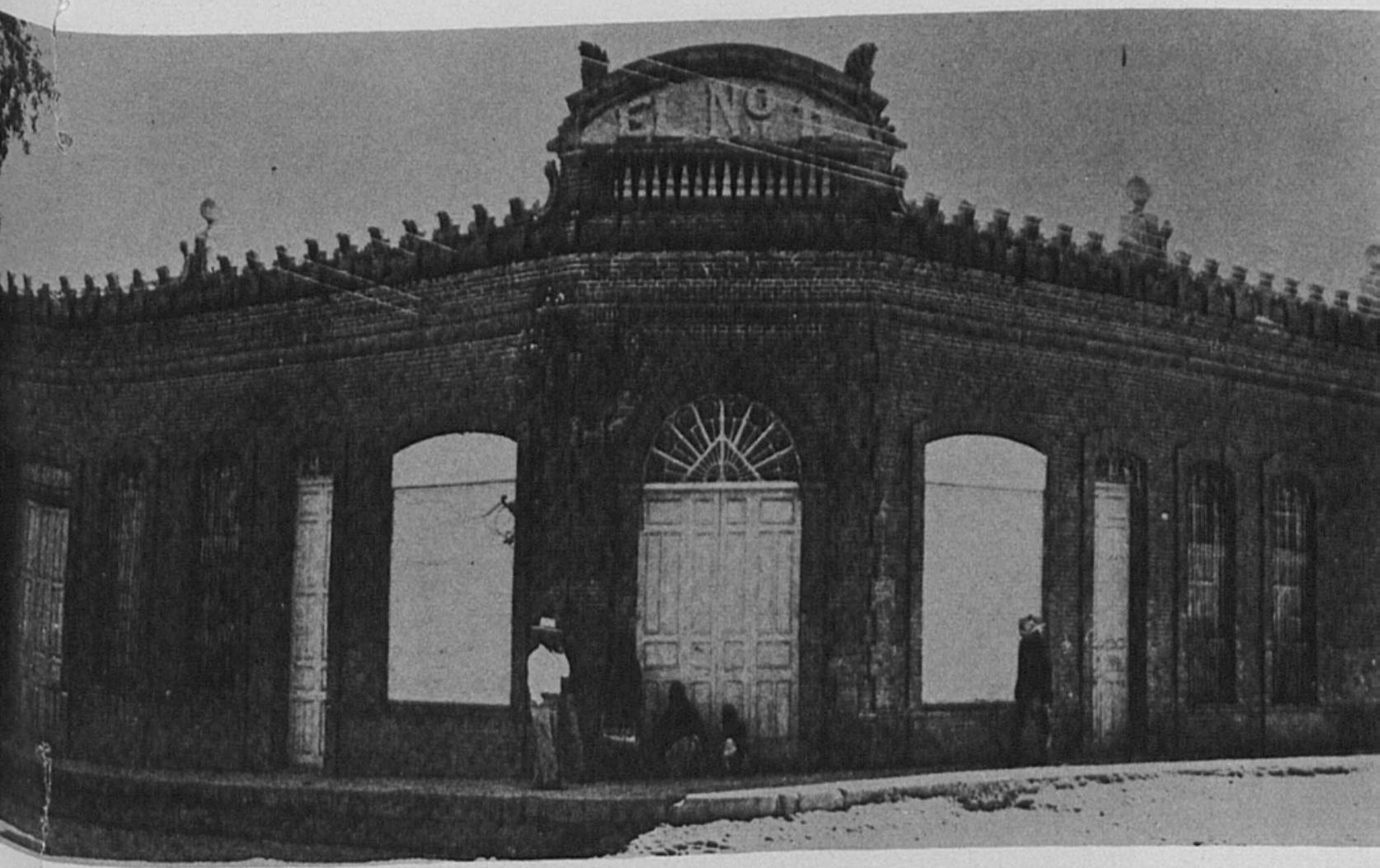




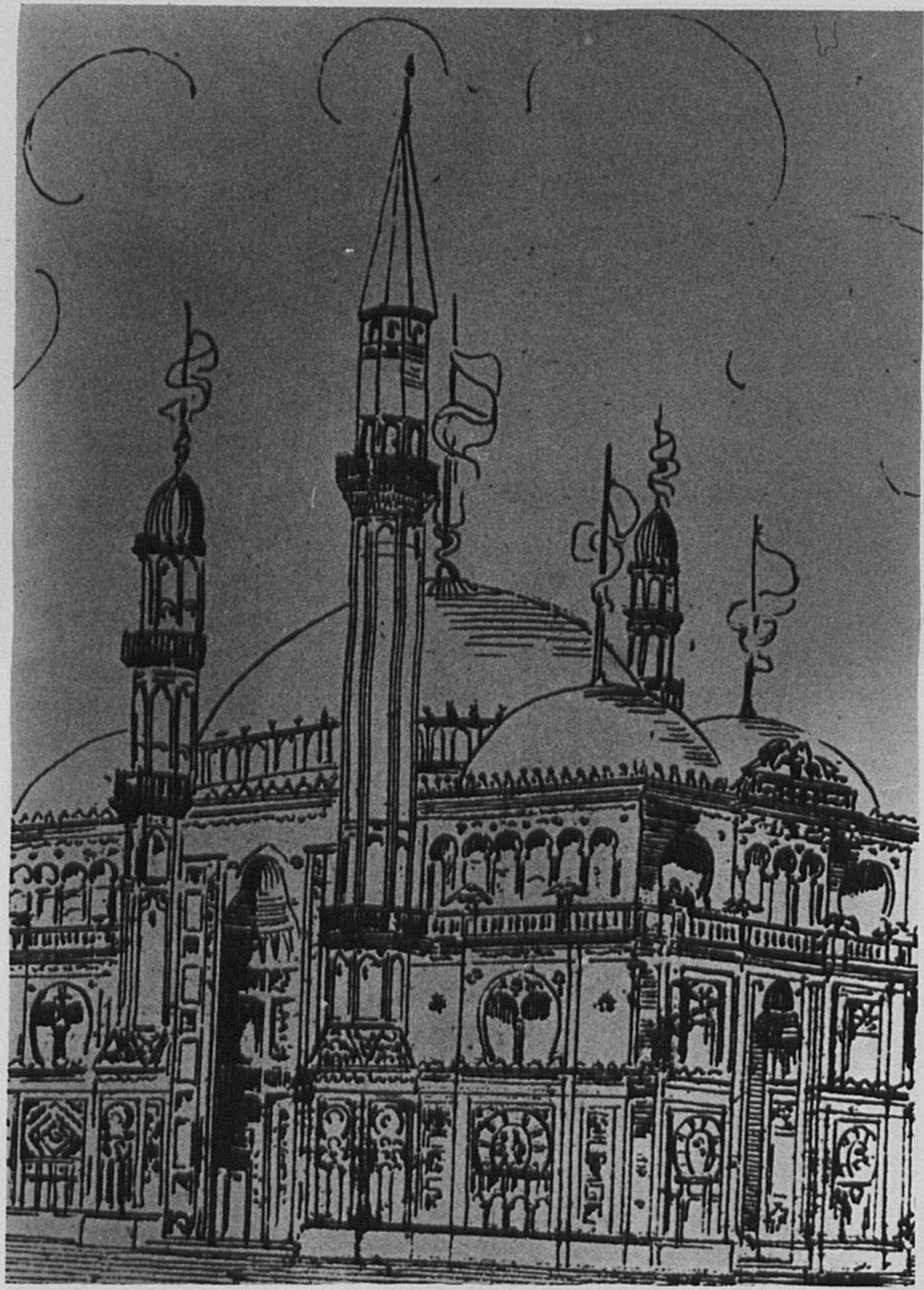

8. Proyecto de edificio de la administración para la Exposición Nacional Mexicana de 1896. Arquitecto W. Mosser. 1895. Foto arquitecto Israel Katzman. 


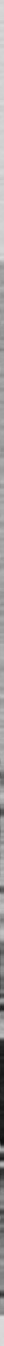

9. Casa en la colonia Juárez. El Mundo Ilustrado, 1898. 


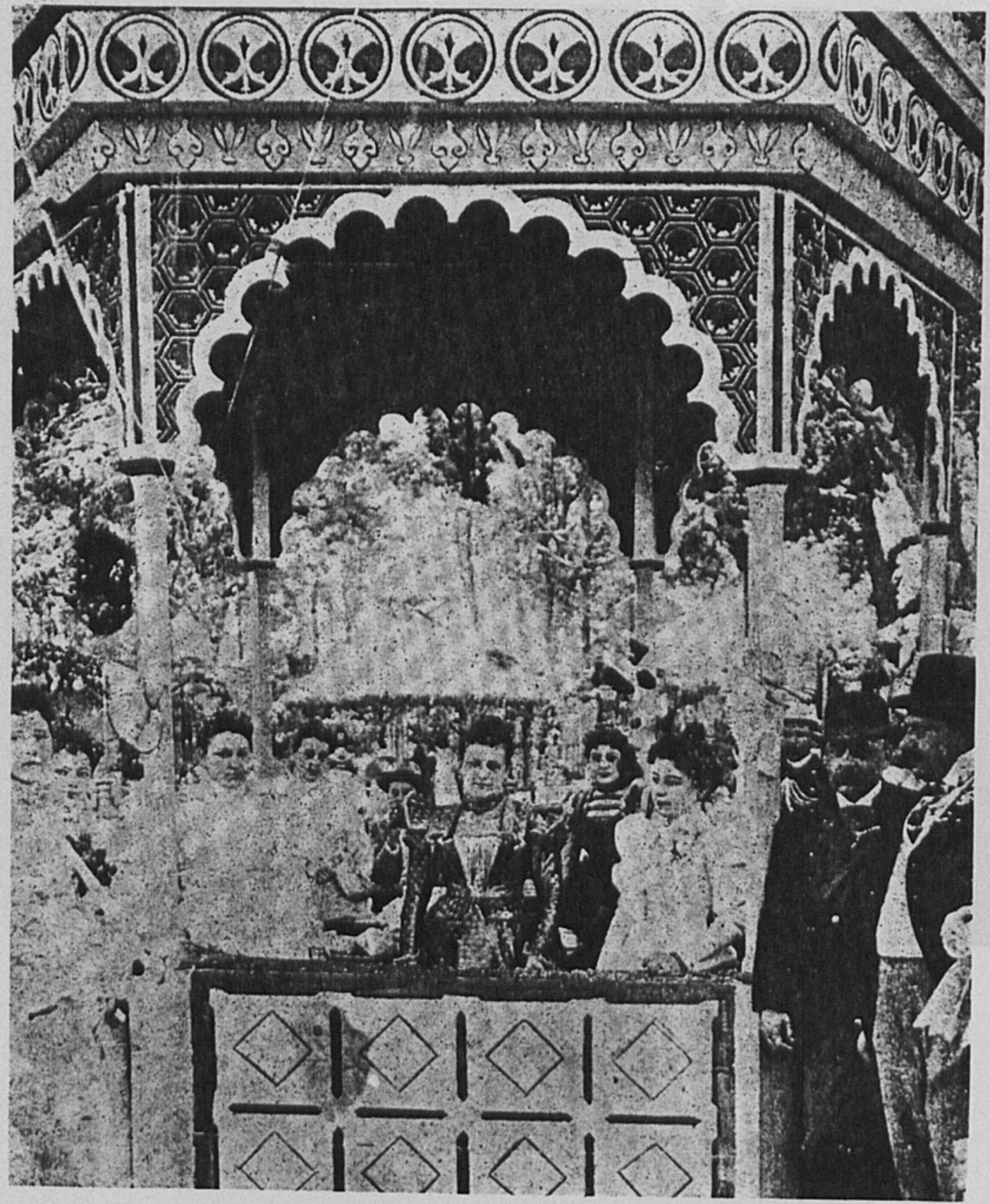

10. Puesto de confeti en la Kermesse de Mixcoac. El Mundo Ilustrado, 1898. 
DOI: http://dx.doi.org/10.22201/iie.18703062e.1976.45.1037

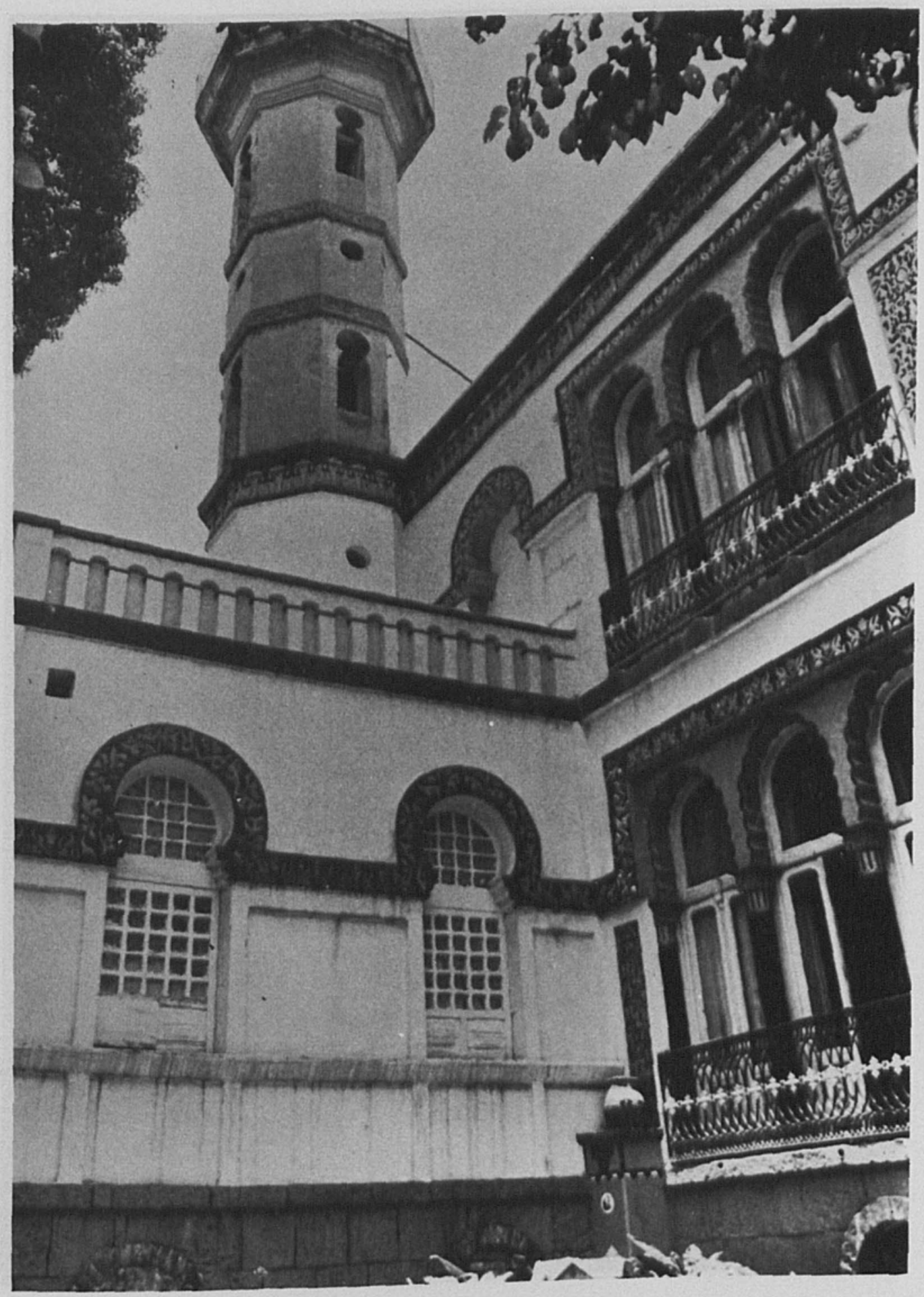

11. Casa esquina de Avenida Revolución y Rubens. Arquitecto Enrique Olaeta. 1903. Foto. E.G.B. 


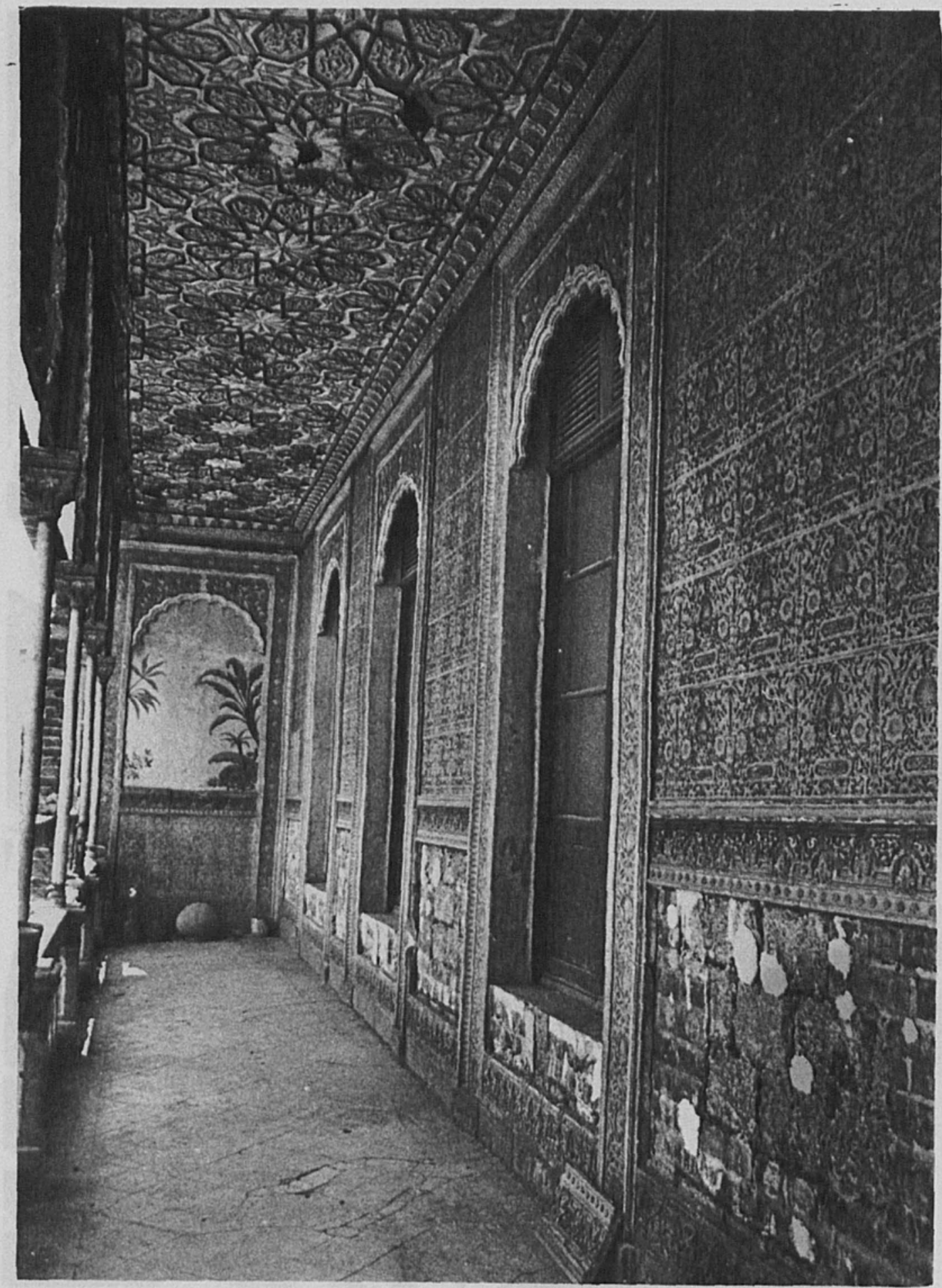

12. Casa en la calle Río Mixcoac esquina con Félix Parra. Foto Pedro Cuevas. 


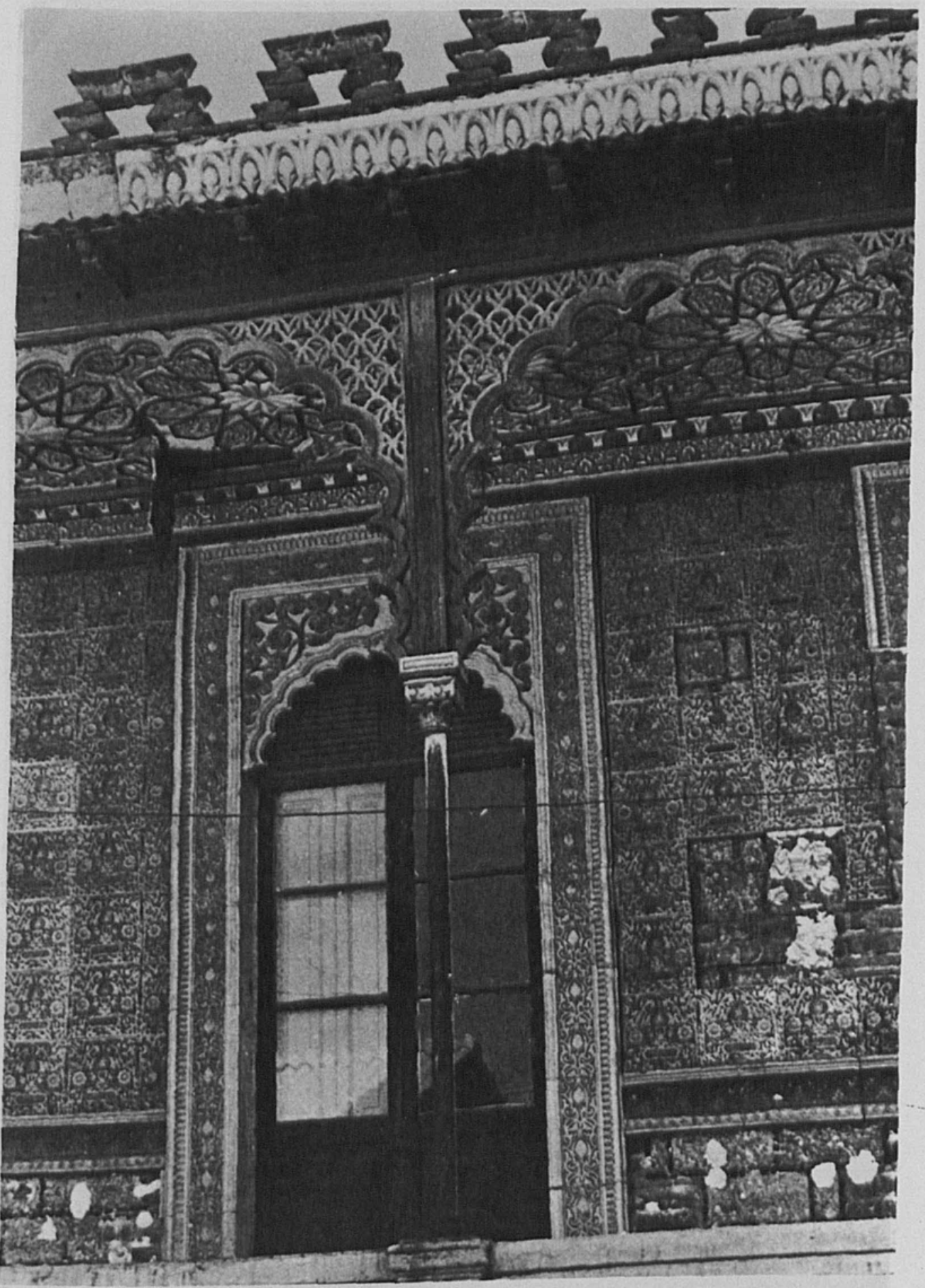

13. Casa calle Río Mixcoac esquina con Félix Parra. Foto Pedro Cuevas. 


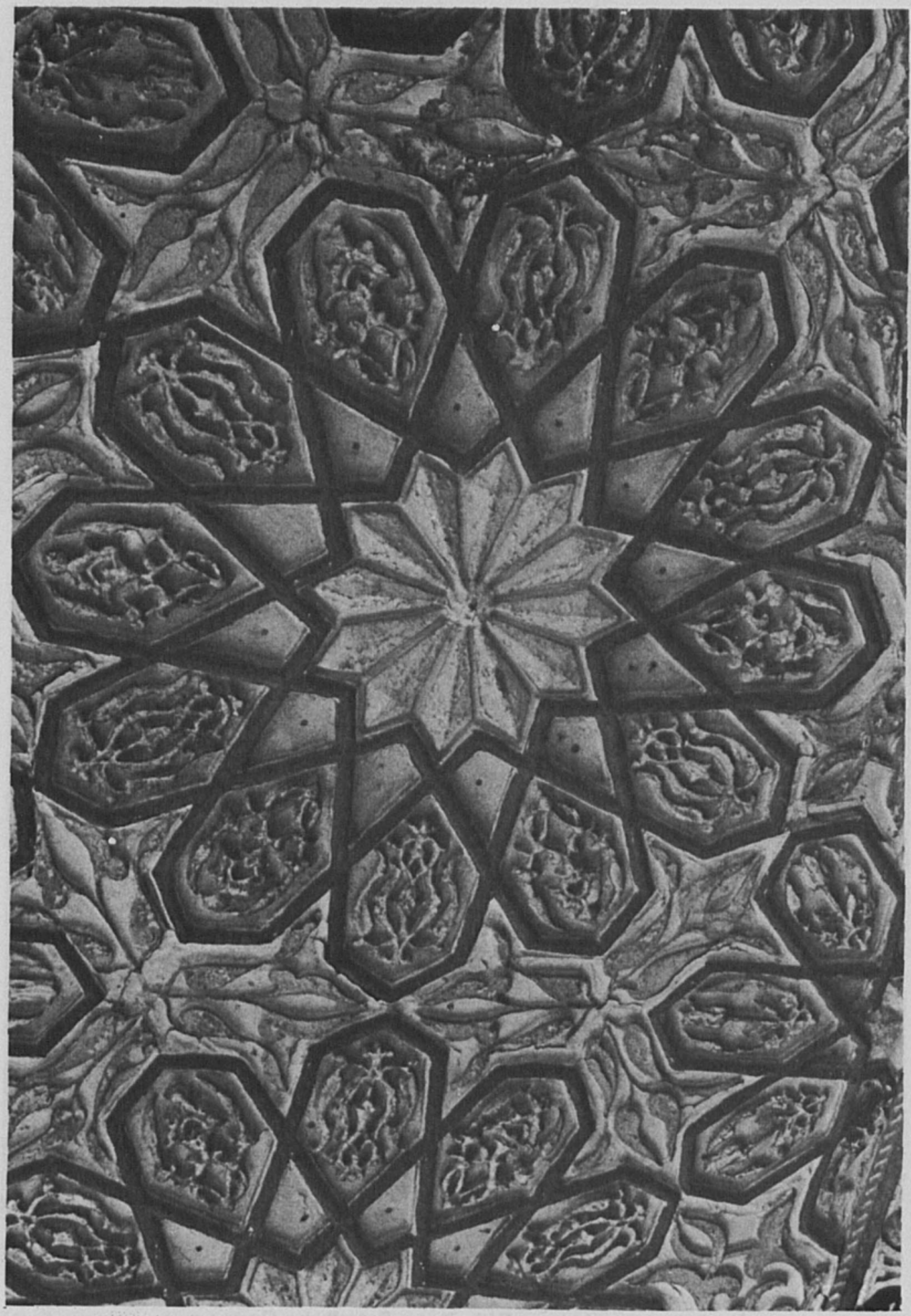

14. Detalle del artesonado, casa Félix Parra y Río Mixcoac. Foto Pedro Cuevas. 


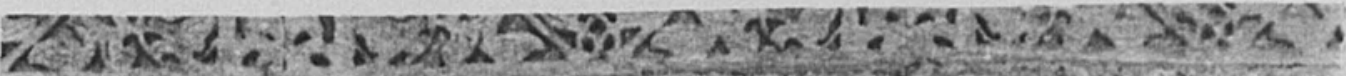

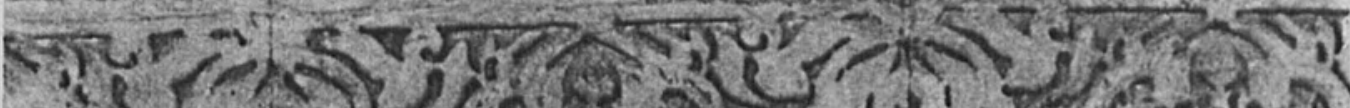

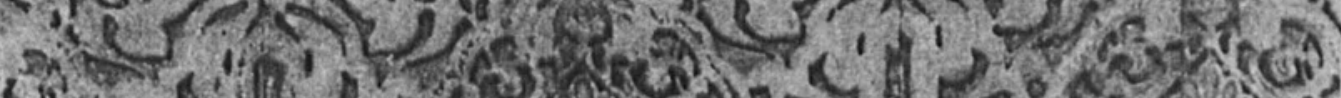

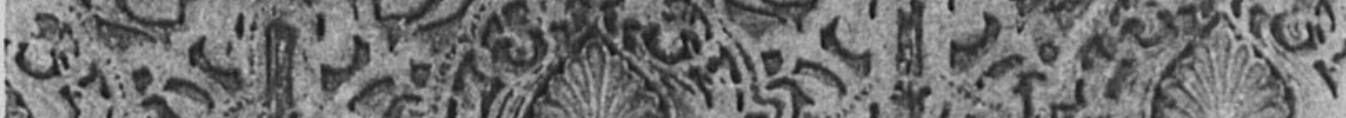

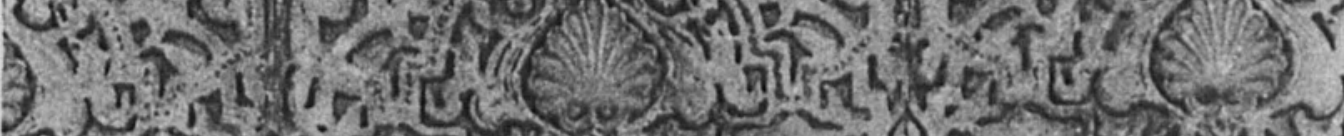

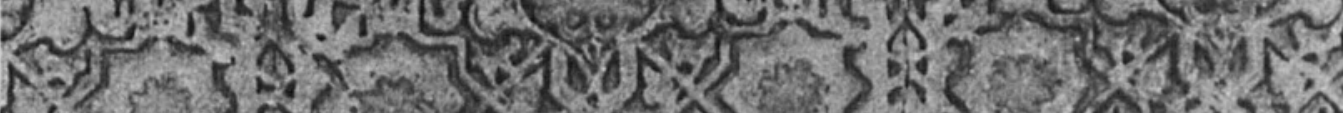

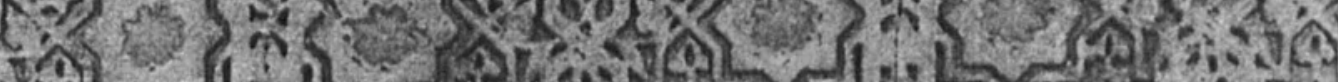

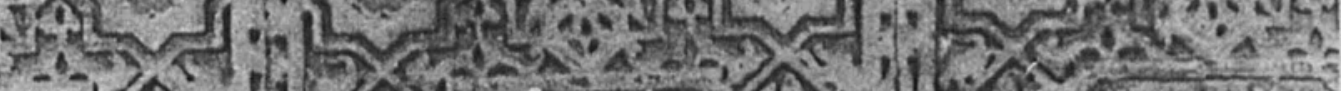

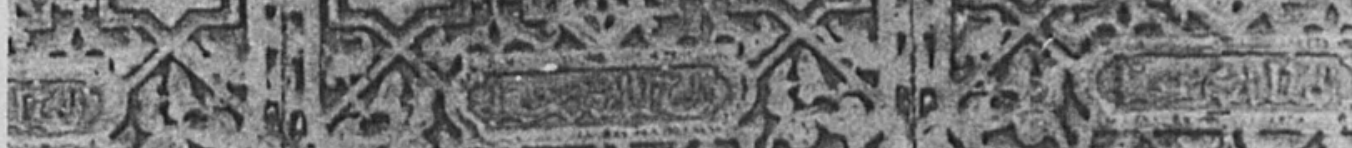

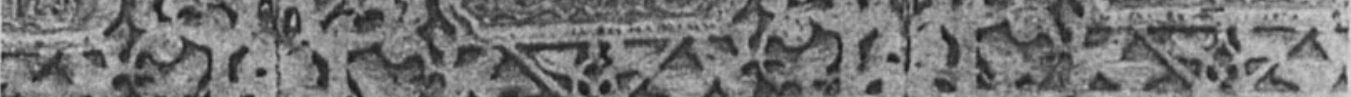

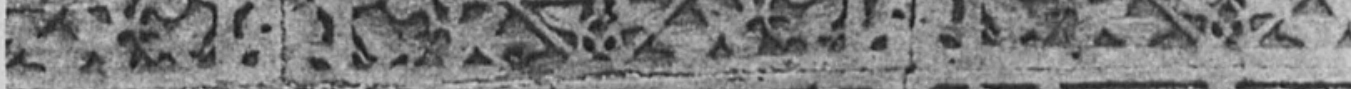

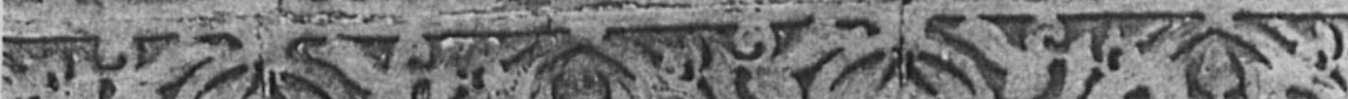

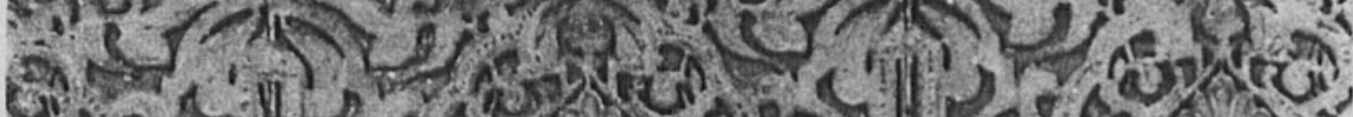

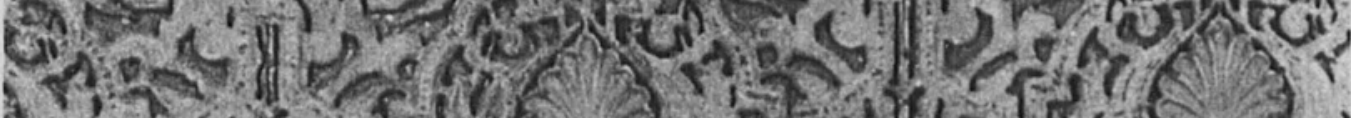

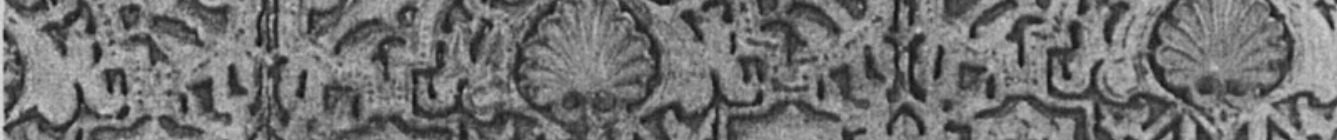

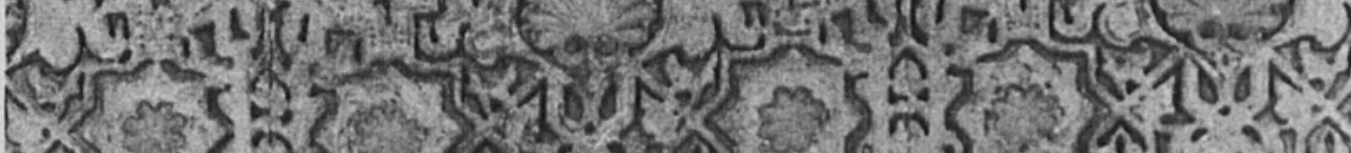

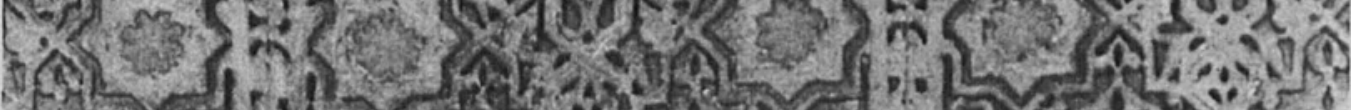

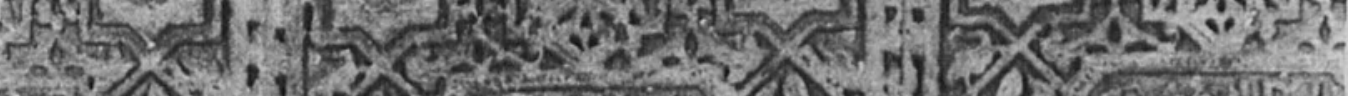

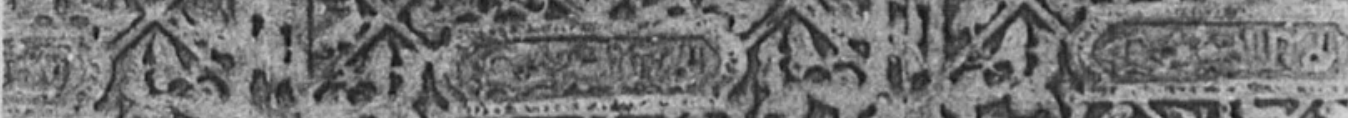

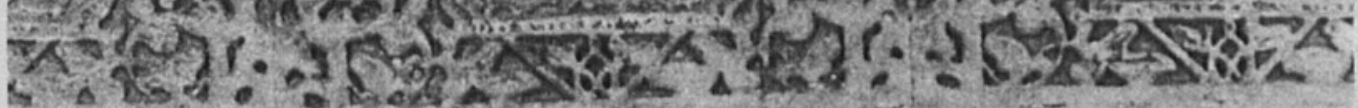

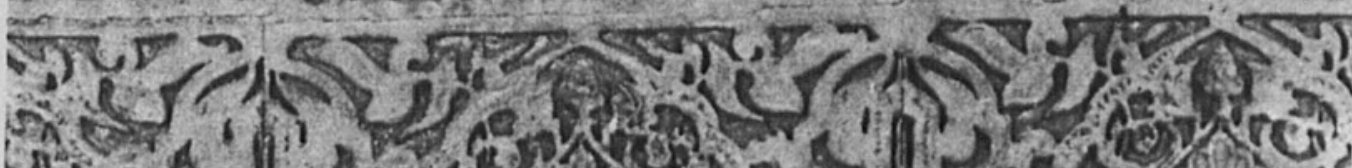

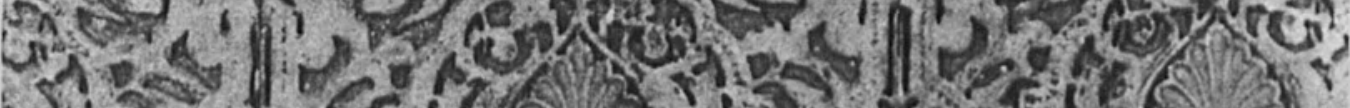

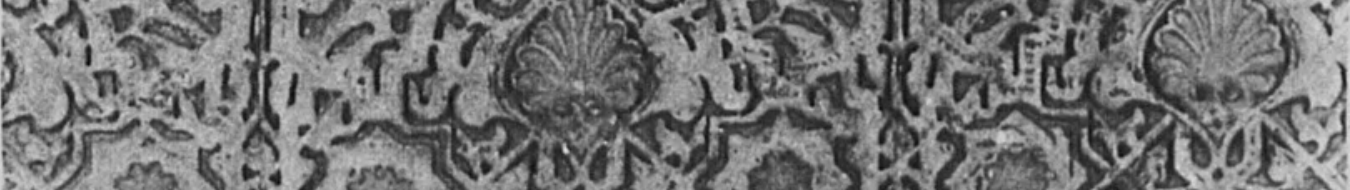

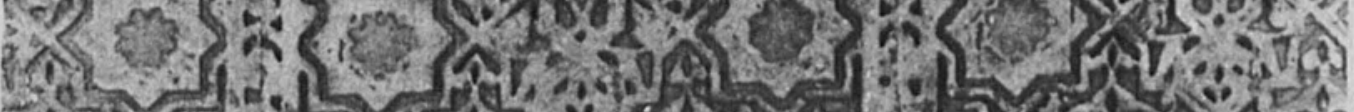
$\because \theta$ C.

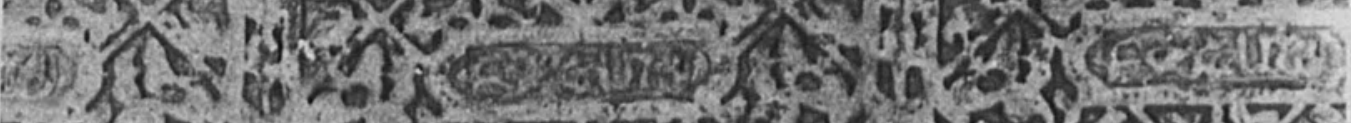

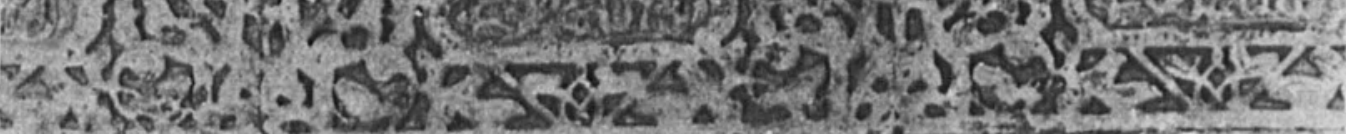

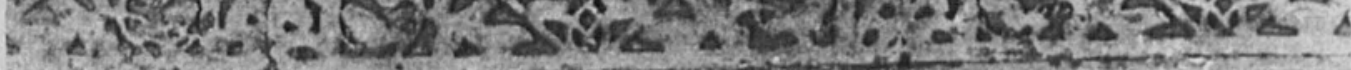

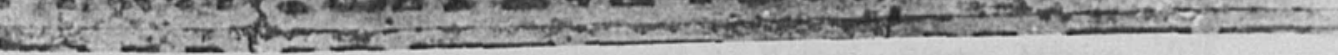

15. Azulejos con relieve de la casa de Félix Parra y Río Mixcoac. Foto Pedro Cuevas. 


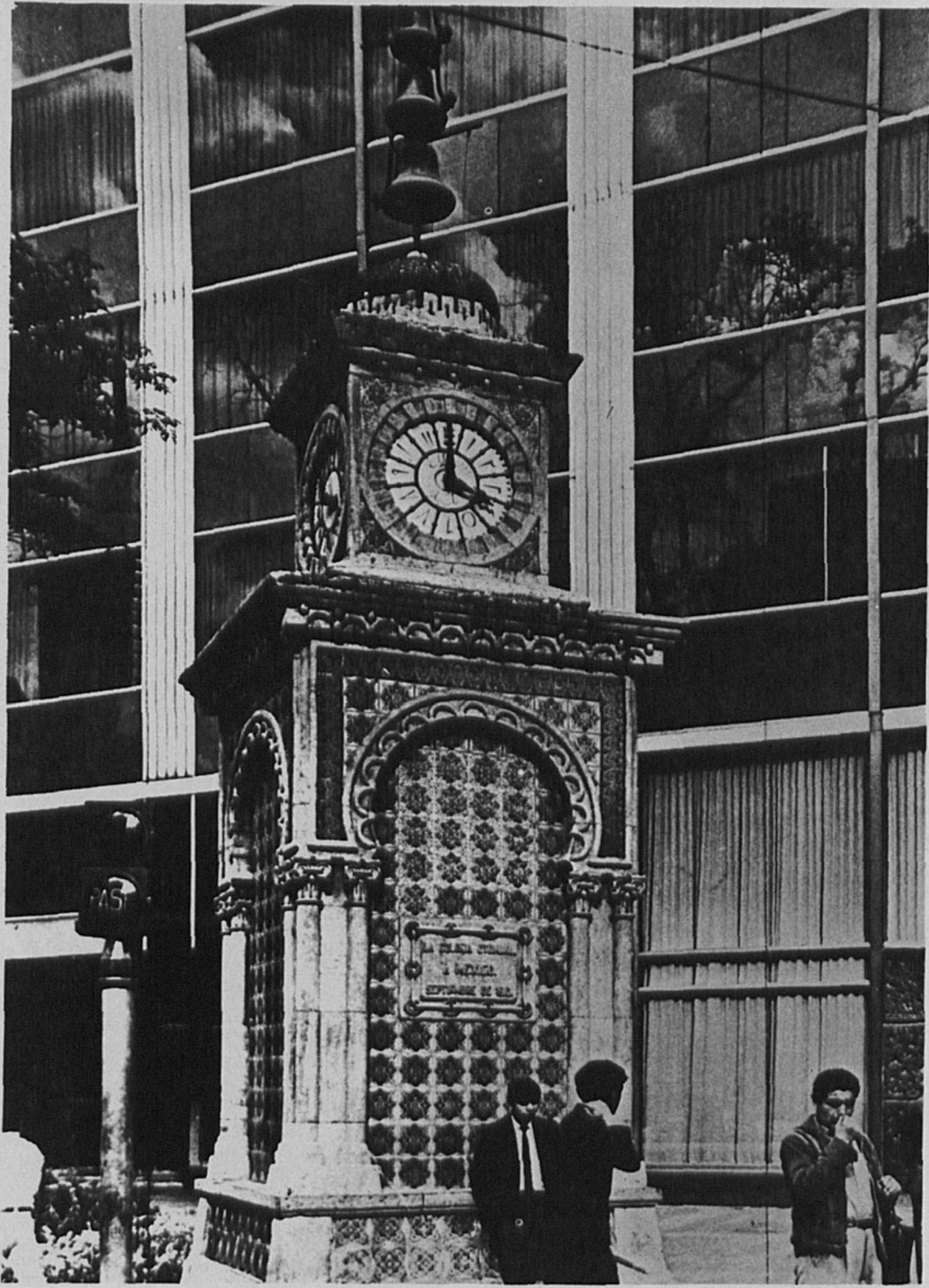

16. Reloj en Bolívar y Venustiano Carranza, 1910. Ingeniero G. M. Oropeza. Foto arquitecto Israel Katzman. 
Juan de Montoro en Zacatecas, la barda del atrio de la iglesia de San Francisco de Adame y la de Río de Medina en Aguascalientes.

Volviendo a las obras hechas por Tamariz en Puebla, hay que agregar que el hospital antes mencionado, también cuenta con un esbelto minarete que corresponde a la torre de su capilla. En 1880 este arquitecto reconstruyó el molino de San Francisco o del Marqués de Monserrat para casa habitación. Los temas empleados en esa reconstrucción son: almenas escalonadas, arcos de herradura y polilobulados, una cúpula de diseño oriental con azulejos policromados que forman dibujos geométricos y un precioso alminar. En 1882, en la misma ciudad levantó un quiosco al centro de la Plaza de la Constitución, de pequeña planta octagonal, azulejos en su base y el resto de la construcción metálica, con delgados soportes de hierro rematados en un pequeño capitel que recuerda los de la Alhambra. En 1883, Tamariz hizo la casa de la "Sociedad de la Purísima Concepción", actualmente del "Círculo Católico", casa ecléctica, con un precioso patio morisco, cuyo piso es de azulejos con diseño geométrico, mientras que las paredes del primer piso, están decoradas con alicatados geométricos, muy a la manera de la Alhambra y un gran lambrín de cerámica con bajorrelieves en los que aparecen lacerías mudéjares. Los vanos de la parte baja tienen arcos polílobulados y en sus enjutas decoración de ataurique y el arco de acceso al patio, en la parte interior, está enmarcado con un alfiz, mientras que, en el segundo piso, todas las puertas de entrada a las habitaciones están rodeadas de ornamentación vegetal hecha con estuco y con una gran libertad, simulan en la parte superior de las mismas, arcos trilobulados.

Un edificio muy moderno por el material de su construcción y totalmente neomorisco por sus temas, es el pabellón construido por el arquitecto Ramón Ibarrola para la Exposición Internacional de Nueva Orleáns de 1884-85 a la que México concurrió. Este pabellón de planta octogonal, posiblemente tuvo como modelo el circo Price de Madrid del arquitecto Agustín Ortiz de Villajos (1880), pues a semejanza de dicho circo, la estructura del pabellón mexicano aportaba la novedad de estar hecho de hierro, trabajado finamente, en el que lacerias y arabescos de este metal, se unían formando afiligranadas celosías a las que el brillo de sus cristales proporcionaba mayor atractivo, junto con delgadas columnillas cuyos capiteles recuerdan la arquitectura granadina. La prestigiada revista española La Ilustración Española y Ame-

9 Villegas, Víctor Manuel, Arguitectura de Refugio Reyes. México, 1973. 
ricana de 8 de noviembre de 1884, al referirse al pabellón mexicano decia: es "un artístico templete octogonal de estilo árabe, cuyos lados reproducen exactamente los más bellos arcos de la Alhambra y del Alcázar de Sevilla". El ingeniero Ibarrola demostraba con esa construcción que, si bien las primeras aplicaciones del hierro, tuvieron un carácter utilitario, este material no estaba reñido de ninguna manera con la belleza. Ese pabellón fue tan del gusto de la época, que al finalizar la exhibición, se colocó en la Alameda Central de la ciudad de México adonde las elegantes del tiempo fueron a tomar helados, hasta el año de 1910. El monumento dedicado a don Benito Juárez, lo desplazó a otra Alameda, la de Santa María la Ribera, lugar en el que se encuentra ahora como hermoso recuerdo de los tiempos románticos, inclinados al exotismo oriental.

Poco después del pabellón hecho por Ibarrola, en las calles ahora de Félix Parra y Río Mixcoac, se construyó una pequeña casa en la que un anónimo arquitecto, en un afán orientalista casi arqueológico e inspirándose en la Alhambra, empleó elementos moriscos. La casa de una planta, la coronan almenas escalonadas, y está rodeada en tres de sus lados por un corredor que en su exterior tiene una arquería de arcos de hierro polilobulados unidos al techo por medio de celosías con arabescos del mismo metal. Sus delgados soportes también de hierro tienen un pequeño capitel como los de la Alhambra. Fue tal el deseo del arquitecto de que todo siguiera el mismo estilo, que las bases de cemento de esas columnillas, ostentan un bajorrelieve en el que aparece un arco polilobulado. Las paredes de la casa que dan al corredor están cubiertas en la parte superior de preciosa cerámica con relieve en tonos azul, rojo $y$ amarillo los que tienen hasta caracteres cúficos (azulejos que con seguridad fueron importados de Andalucia). En la parte baja las paredes se cubren con un lambrín de alicatados en estuco, de ornamentación vegetal y lacerías geométricas. Los techos imitan artesonados de madera, de pauta mudéjar a base de rombos, estrellas y lazos; están hechos con cartón comprimido y debieron adquirirse en algunas de las casas dedicadas a vender materiales prefabricados para construcciones, pues el mismo diseño y material se dará en obras posteriores realizadas en Puebla. Los trabajos de carpintería de esa casa también presentan formas orientales y sus celosías son un verdadero encaje en madera. Para ambientar mejor la construcción había al frente de la casa dos fuentes con lacerías mudéjares, según afirma su actual propietario. El fondo de cada uno de los corredores laterales está adornado con pinturas al fresco de 
tema exótico. Pronto desaparecerá esta casa de la que aquí se deja constancia.

La construcción anterior podría formar parte de lo que Navascues Palacio, en su obra ya citada, encasilla dentro de lo que él llama fenómeno de "Alhambrismo".

Ejemplo interesante de un edificio completo dentro de lo que se denomina pastiche arábigo, se encuentra también en Mixcoac, en la esquina de avenida Revolución y Rubens. Es una casa de grandes dimensiones a la que no le falta ni su minarete con ventanitas de arco de herradura. Fue construida en 1903 por el arquitecto Enrique Olaeta, para residencia de uno de los magnates de la época porfirista, don Francisco $I$. Serralde. Olaeta emplea como elementos decorativos los arcos de herradura y polilobulados, el estuco policromado que con una ornamentación vegetal y de caracteres cúficos, cubre parte de los muros $y$, en forma de franja, sube y baja por la fachada encuadrando las ventanas y puertas a manera de alfiz. Las columnas que soportan algunos de los arcos están cubiertas de estuco que imitan mármoles negros y lucen capiteles de tipo granadino. Esta casa que vio mejores tiempos y cuya fachada principal fue totalmente destruida para ensanchar la avenida Revolución, contó con un mobiliario morisco completo, según cuentan sus actuales dueños, descendientes del licenciado Serralde, muebles de los que sólo quedan los grandes aparadores del comedor con arcos polilobulados y rematados por una graciosa crestería de pequeños merlones escalonados.

La vertiente orientalista de la arquitectura ecléctica, fundió las formas mudéjares con otras más islámicas, produciendo el movimiento que podríamos llamar pastiche arábigo. A ello se asoció el interés por lo musulmán, fomentado principalmente por las letras. La bibliografía histórico-artística sobre el mundo musulmán o árabe como entonces se le llamaba, aparte de ser muy vasta, se nutrió durante ese tiempo con los cuentos y poemas publicados en la prensa periódica, sobre todo en las revistas ilustradas. A ese impulso arabista, hay que sumar la importancia que tuvo la actitud favorable de la Academia de Bellas Artes en la que se efectuaron exposiciones con temas orientales. En la de enero de 1889, el pintor Luis Gash expuso su cuadro al óleo "Canción árabe", y también en la de 1903, el pintor pompier Antonio Fabrés, bastante inclinado a esos asuntos (su estudio estaba decorado en estilo árabe), presentó varias acuarelas con títulos como: "Leyendo el Corán".

La corriente del pastiche arábigo dio lugar a la construcción de patios moriscos a la manera de Sevilla o de Córdoba, como el de la casa del 
doctor Aureliano Urrutia en Xochimilco, y a los salones fumadores que proliferaran en la ciudad de México. El arquitecto Antonio Rivas Mercado, hizo un salón de éstos en el Palacio Nacional, y hubo otros en las principales ciudades de provincia. En Puebla los hermanos Arpa se dedicaron a hacer preciosas decoraciones de estucos con temas granadinos y artesones prefabricados. El pastiche arábigo se usó mucho además, en la ornamentación de interiores de teatros, pues la decoración árabe parecía estar especialmente vinculada a los edificios públicos de esparcimiento. Buena muestra es el extraordinario teatro Juárez de la ciudad de Guanajuato - que todavía podemos gozar- diseñado también por el arquitecto Rivas Mercado. Tan lograda es esta obra dentro de su intención que pos hace reflexionar hasta qué grado sea justo llamarlos pastiches con tono peyorativo. A los anteriores ejemplos pueden añadirse otros de menor importancia, como los arcos triunfales levantados para festejar las fiestas patrias o los puestos para vender refrescos y confeti en las kermeses, etcétera, etcétera.

Otros muchos casos podrian citarse, pero lo que en rigor significa todo este orientalismo, es la libertad del artista frente al estilo único de la Academia, que en los últimos años del siglo xIx y primeras décadas del presente, llevó a muchos de ellos a dar gusto a la sociedad para la que trabajaron y realizar así, obras importantes del estilo evocador del oriente islámico $\mathrm{y}$, por qué no, de ese mudejarismo tan arraigado en Espana y también en el virreinato de México. 